\title{
IDENTIFIKASI MOLEKULER CENDAWAN ENTOMOPATOGEN Beauveria Bassiana DAN Metarhizium Anisopliae ASAL ISOLAT CIANJUR
}

\author{
Disusun oleh : \\ Widya Sari**) \\ Chindy Nur Rosmeita*)
}

\begin{abstract}
Abstrak
Beauveria bassiana dan Metarbizium anisopliae merupakan cendawan entomopatogen yang telah banyak dimanfaatkan sebagai agens biokontrol untuk mengendalikan hama serangga. Metode identifikasi organisme sampai tingkat spesies salah satunya dapat melalui identifikasi molekuler. Keberhasilan analisis molekuler dengan teknik PCR bergantung pada kualitas DNA yang diekstraksi. Tujuan penelitian ini adalah menentukan metode ekstraksi yang tepat untuk menghasilkan kemurnian DNA yang tinggi dan mengidentifikasi secara molekuler isolat B. bassiana dan M. anisopliae asal tanaman padi Cianjur dengan teknik PCR menggunakan primer universal ITS1/ITS4. Penelitian dilaksanakan di Balai Penelitian Tanaman Hias Segunung dari bulan Maret sampai Juli 2019. Isolat yang diidentifikasi merupakan koleksi BPTPH Bojongpicung dan BALITHI Segunung. Ekstraksi DNA dilakukan menggunakan bufer CTAB dan SDS. Isolat cendawan yang diekstrasi menggunakan $\mathrm{CTAB}$ menunjukkan kemurnian yang bagus dengan nilai 1.8-2.0 dan isolat hasil ekstraksi dengan SDS menunjukkan kemurnian kurang dari 1.8. Primer ITS1/ITS4 telah berhasil mengamplifikasi daerah internal transcribed spacer dari isolat B. bassiana pada ukuran $600 \mathrm{bp}$ dan isolat M. Anisopliae pada ukuran kisaran 550-600 bp.
\end{abstract}

Kata kunci: Beawveria bassiana, Metarbiæium anisopliae, CTAB, SDS, ITS1/ITS4.

\begin{abstract}
Abstrac
Beauveria bassiana and Metarbizium anisopliae are the entomopathogenic fungi that bave been utilized as biocontrol agents in controlling the pests. The method of identifying organisms to a level of species can be through molecular identification. The success of molecular analysis with PCR technique depends on the quality of DNA extraction. The purposes of this research were to determined the right extraction method to produce high purity of DNA and identify molecularly the isolates of B. bassiana and M. anisopliae from Cianjur rice plant with PCR technique using universal primer ITS1/ITS4. The research bas been implemented in Balai Penelitian Tanaman Hias Segunung from March to July 2019. The isolates have identified is a collection of BPTPH Bojongpicung and BALITHI Segunung. The DNA extraction was using $C T A B$ and SDS buffer. The isolates have extracted use CTAB buffer showed good purity of DNA with value 1.8-2.0 and isolates the extraction results with SDS buffer showed no good purity was 1.8. Primers ITS1/ITS4 has successfully amplified the internal transcribed spacer region from B. bassiana at the size $600 \mathrm{bp}$ and M. anisopliae at the size between 550-600 bp.
\end{abstract}

Keywords: Beauveria bassiana, Metarbizium anisopliae, CTAB, SDS, ITS1/ITS4.

*) Alumni Fakultas Sains Terapan UNSUR

**) Dosen Fakultas Sains Terapan UNSUR

IDENTIFIKASI MOLEKULER CENDAWAN

WIDYA SARI

ENTOMOPATOGEN Beauveria Bassiana DAN

Metathizium Anisopliae ASAL ISOLAT

CHINDY NUR ROSMEITA

CIANJUR 


\section{PENDAHULUAN}

Cendawan entomopatogen merupakan cendawan penyebab penyakit pada serangga dan menginfeksi secara spesifik terhadap serangga tertentu dengan efek samping dan risiko yang sangat rendah bagi serangga non target (Septiana, 2015). Beawveria bassiana dan Metarbizium anisopliae adalah jenis cendawan entomopatogen yang telah banyak dimanfaatkan dalam mengendalikan hama.

B. bassiana merupakan cendawan yang dapat menginfeksi hama dari Ordo Lepidoptera, Coleoptera, Hymenoptera, Hemiptera, dan Diptera (Wartono et al., 2016). Serangga yang terinfeksi B. bassiana akan mengeras dan mengeluarkan miselium berwarna putih (Suprayogi, 2015) yang memiliki racun beawvericin yang berfungsi untuk merusak jaringan tubuh serangga (Ikawati et al., 2017). Toksin yang diproduksi oleh $B$. bassiana antara lain beawvericin, bassianolidae, cyclosporine $A$, dan oosporein (Ladja, 2009).

M. anisopliae mempunyai kapasitas reproduksi yang tinggi, siklus hidup yang pendek, dapat membentuk spora yang tahan lama di alam meskipun dalam kondisi yang tidak menguntungkan, aman, selektif, mudah diproduksi, dan kecil kemungkinan terjadi resistensi hama (Rustama et al., 2008). M. anisopliae mampu menginfeksi hama dari Ordo Coleoptera, Isoptera, Homoptera, Hemiptera, dan Lepidoptera (Strack, 2003 dalam Trizelia $e t$ al., 2010) dan memiliki miselium berwarna hijau zaitun yang terlihat dari serangga yang terinfeksi (Aisyah, 2015). Toksin destruxin yang dihasilkan oleh $M$. anisopliae berperan sebagai pematah pertahanan serangga inang (Salim dan Hosang, 2013).

$$
\text { Kemampuan cendawan }
$$

entomopatogen dalam mematikan serangga dipengaruhi oleh karakter fisiologi dan genetik cendawan (Trizelia, 2005). Keragaman genetic dapat dilihat sebagai salah satu yang menguntungkan di dalam pengedalian hayati serangga dan dapat diteliti menggunakan analisis molekuler. Keberhasilan analisis molekuler dengan teknik PCR bergantung pada kualitas DNA yang diekstraksi dengan berbagai bufer ekstraksi misalnya SDS (Sodium Dodecyl Sulfate) dan CTAB (Cetyltrimetbylammonium bromide). Proses identifikasi molekuler diawali dengan ekstraksi DNA, dimana DNA yang digunakan merupakan DNA total yang terbebas dari komponen-komponen penyusun sel. Kemurnian DNA yang dihasilkan mempengaruhi pita DNA yang terbentuk pada proses elektroforesis. Selanjutnya adalah teknik PCR. Aplikasi PCR sudah umum diterapkan dalam bidang penyakit tanaman termasuk untuk cendawan (Nurhasanah, 2012). Maka dari itu perlu dilakukan analisis secara molekuler menggunakan teknik PCR pada cendawan entomopatogen B. bassiana dan $M$. anisopliae asal tanaman padi Cianjur. Penelitian ini bertujuan untuk mengetahui pengaruh perbedaan larutan bufer ekstraksi terhadap kemurnian DNA dan mengetahui perbedaan hasil amplifikasi PCR pada isolat cendawan entomopatogen $B$. bassiana dan $M$. anisopliae asal tanaman padi Cianjur.

\section{METODE PENELITIAN}

\section{Tempat dan Waktu}

Penelitian ini dilakukan di Laboratorium milik Balai Penelitian Tanaman Hias Segunung (BALITHI), pada bulan Maret sampai dengan Juli 2019.

\section{Alat dan Bahan}

Alat yang digunakan dalam penelitian ini adalah petridish, panci, sendok, timbangan ohause, kaca preparat, sprayer, mortar, pastle, ice block, cool box, micropipette, micropipettetip, rak micropipette, microtube eppendorf $1.5 \mathrm{~mL}$, microtube Eppendorf $0.5 \mathrm{~mL}$, rak microtube, waterbath, sentrifuge (Thermo Scientific ${ }^{\mathrm{TM}}$ ), baker glass, gelas ukur, labu erlenmeyer, spatula, 
parafilm, vortex, timbangan analitik, $\mathrm{pH}$ meter, hotplate, autoklaf, freezer $-20^{\circ} \mathrm{C}$, microwave, PCR macbine (Sensquest Lab Cycler), NanoPhotometer (Implen), mesin elektroforesis, geldoc digital imaging system.

Bahan yang digunakan adalah isolat murni Beawveria bassiana asal tanaman padi dan Metarbizium anisopliae asal tanaman padi sebagai sampel utama sedangkan $B$. bassiana asal tanaman Pisang dan $M$. anisopliae asal tanaman Jagung sebagai kontrol positif, kentang, dextrose agar, antibiotic (Streptomycin), aquades steril, tisu kering, $500 \mu \mathrm{L}$ bufer ekstraksi CTAB (10\% Cetyltrimethylammonium Bromide (CTAB) $10 \mathrm{~mL} ; \quad 0.5 \mathrm{M}$ Ethylene Diammine Tetraacetic Acid (EDTA) pH $8.02 \mathrm{~mL} ; 1 \mathrm{M}$ Tris- $\mathrm{HCl} \mathrm{pH} 8.05 \mathrm{~mL} ; 5$ $\mathrm{M} \mathrm{NaCl} 12.6 \mathrm{~mL}$; aquades steril $100 \mathrm{~mL}$; 2-Mercapto Ethanol $1 \mathrm{~mL})$, Chlorofom : Isoamyl alcohol (C : I, $24: 1, \mathrm{v} / \mathrm{v})$, Isopropanol, etanol $70 \%$, bufer TE (1 M Tris- $\mathrm{HCl}$ pH $8.01 \mathrm{~mL} ; 0.5 \mathrm{M}$ EDTA 0.2 $\mathrm{mL}$; aquades steril $100 \mathrm{~mL}$ ), bufer ekstraksi SDS (200 mM Tris- $\mathrm{HCl}$ pH 8.5; $250 \mathrm{mM} \mathrm{NaCl} ; 25 \mathrm{mM}$ EDTA; 0.5\% Sodium Dodecyl Sulfate (SDS); aquades steril $100 \mathrm{~mL})$, Phenol : Chloroform : Isoamyl alcohol (P : C : I, $25: 24: 1, \mathrm{v} / \mathrm{v})$, amonium asetat, DreamTaq PCR (Thermo Scientific), ddH2O (Nuclease free water) (Thermo Scientific), marker ukuran $1 \mathrm{~kb}$ (Thermo Scientific), ITS1 dan ITS4
(Thermo Scientific), Agarose, TBE 0.5x, Loading dye (Thermo Scientific), Nucleic Acid Gel Stain (SMOBIO).

\section{Metode Penelitian}

Penelitian ini dilakukan dengan metode eksperimental di Laboratorium BALITHI menggunakan Rancangan Acak Lengkap Faktorial (RALF) pada empat cendawan yaitu B. bassiaa asal Padi, B. bassiana asal Pisang, M. anisopliae asal Padi dan M. anisopliae asal Jagung serta dua jenis bufer ekstraksi yaitu CTAB dan SDS dengan 3 kali ulangan, sehingga terdapat 24 unit percobaan untuk data kuantitatif. Sedangkan data kualitatif menggunakan metode analisis deskriptif.

\section{Penyiapan Isolat Murni Cendawan Entomopatogen}

Isolat cendawan yang digunakan merupakan koleksi Laboratorium Balai Perlindungan Tanaman Pangan dan Hortikultura (BPTPH) Wilayah I Cianjur dan Laboratorium Mikologi Balai Penelitian Tanaman Hias (BALITHI) KP Segunung yang terlihat pada Tabel 1. Isolat hasil koleksi diinokulasikan pada media PDA (Potato Dextrose Agar) kemudian dibiarkan tumbuh selama 2-7 hsi pada suhu $25^{\circ} \mathrm{C}$ sampai tumbuh miselia (Nirmalasari, 2015).

Tabel 1. Isolat cendawan yang digunakan sebagai sampel.

\begin{tabular}{lllll}
\hline Kode Isolat & \multicolumn{1}{c}{ Spesies } & \multicolumn{1}{c}{ Asal } & Vegetasi & \multicolumn{1}{c}{ Sumber } \\
\hline $\mathrm{BbP}$ & Beauveria bassiana & BPTPH & Padi & Serangga \\
$\mathrm{BbPs}$ & Beauveria bassiana & BALITHI & Pisang & Serangga \\
$\mathrm{MaP}$ & Metarizhium anisopliae var. anisopliae & BPTPH & Padi & Serangga \\
$\mathrm{MaJg}$ & Metarhizium anisopliae var. anisopliae & BALITHI & Jagung & Serangga \\
\hline
\end{tabular}

\section{Ekstraksi DNA Cendawan}

Ekstraksi DNA miselium
cendawan yang berumur 4 hsi dilakukan dengan metode Abd-Elsalam et al. (2003) dengan modifikasi. Miselium yang dibiakan pada media PDA sebanyak $0.2 \mathrm{~g}$ dikerok menggunakan kaca preparat dengan perlahan agar media tidak terbawa. Miselium dimasukkan kedalam mortar beku kemudian ditambahkan bufer ekstraksi sebanyak $500 \mu \mathrm{L}$ yang bufer ekstraksi (CTAB) dan digerus. Hasil gerusan dimasukkan kedalam microtube berukuran $1.5 \mathrm{~mL}$. inkubasi suspensi di waterbath pada suhu $650 \mathrm{C}$ selama 60 menit. Suspensi dihomogenasi dengan dibolak-balik secar perlahan selama 10 menit kemudian ditambahkan $500 \mu \mathrm{L}$ C:I (24:1, v/v) dingin kedalam suspensi dan disentrifugasi pada kecepatan $3500 \mathrm{rpm}$ selama 20 menit pada suhu 4oC. supernatan dipindahkan ke microtube 
baru selanjutnya tambahkan $1 \mathrm{x}$ volume isopropanol dingin dan dikocok secara perlahan. Endapkan pelet DNA dengan sentrifugasi pada kecepatan $12.000 \mathrm{rpm}$ selama 20 menit. Supernatant dibuang dan pelet dicuci dengan etanol dingin $70 \%$ kemudian disentrifugasi dengan kecepatan $8000 \mathrm{rpm}$ selama 5 menit. Keringanginkan DNA beberapa menit, lalu DNA dilarutkan dalam $75 \mu \mathrm{L}$ bufer TE 1 $\mathrm{x}$ dan disimpan pada suhu $-20 \mathrm{oC}$ untuk mempertahanan kualitas DNA (Porebski et al., 1997).

Ekstraksi DNA dari miselium cendawan yang berumur 4 hsi menggunakan metode Trizelia (2005) dengan modifikasi. Miselium dikerok menggunakan kaca preparat secara perlahan. Miselium sebanyak $50 \mu \mathrm{g}$ dimasukkan kedalam mortar beku kemudian ditambahkan bufer ekstraksi (SDS) sebanyak $500 \mu \mathrm{L}$. hasil gerusan dimasukkan kedalam microtube $1.5 \mathrm{~mL}$ dan dihomogenasi dengan vortex selama 1-2 menit. Suspensi diinkubasi pada suhu 37 oC selama 30-40 menit. Kemudian suspensi ditambahkan 1 volume P:C:I (25:24:1) dingin dan divortex. Suspensi disentrifugasi pada kecepatan $11.000 \mathrm{rpm}$ selama 15 menit pada suhu 4oC. supernatan dipindahkan ke microtube baru dan ditambahkan 1 volume isopropanol dingin kemudian dihomogenasi perlahan. Larutan disentrifugasi pada kecepatan $11.000 \mathrm{rpm}$ selama 10 menit. Supernatant dibuang dan pelet yang didapatkan dicuci dengan etanol dingin $70 \%$. Etanol dibuang dan pelet dikeringanginkan beberapa menit. Pelet DNA dilarutkan dalam $100 \mu \mathrm{L}$ bufer TE 1x dan disimpan pada suhu - 20oC untuk mempertahankan kualitas DNA (Porebski et al., 1997).

\section{Polymerase Chain Reaction (PCR) \\ DNA hasil ekstraksi}

diamplifikasi dengan teknik PCR berdasarkan metode White et al., 1990. Proses amplifikasi dilakukan pada mesin PCR (Sensquest Lab Cycler). Amplifikasi menggunakan primer universal yaitu ITS1 (5'-TCC GTA GGT GAA CCT TGC GG-3') dan primer ITS4 (5'-TCC TCC GCT TAT TGA TAT GC-3'). Sebanyak 2 $\mu \mathrm{L}$ DNA template dimasukan kedalam 25 $\mu \mathrm{L}$ larutan campuran PCR yang terdiri atas $12.5 \mu \mathrm{L}$ DreamTaq PCR, $8.5 \mu \mathrm{L}$ ddH2O, $1 \mu \mathrm{L}$ primer ITS1, dan $1 \mu \mathrm{L}$ primer ITS4. Proses PCR melalui beberapa tahapan, yaitu predenaturasi pada suhu $95 \mathrm{oC}$ selama 5 menit dan sebanyak 30 siklus amplifikasi dengan suhu denaturasi 94oC selama 30 detik, penempelan primer atau annealing $\mu \mathrm{L}$ Nucleic Acid Gel Stain (SMOBIO), agarose dituangkan pada cetakan dengan hole dan didiamkan \pm 30 menit. DNA template sebanyak $7 \mu \mathrm{L}$ dicampurkan dengan $1 \mu \mathrm{L}$ Loading dye. Elektroforesis dilakukan dengan tegangan 75 volt selama 90 menit.

\section{Teknik Pengumpulan Data}

Data kuantitatif yang diperoleh dalam penelitian ini yaitu hasil perhitungan kemurnian DNA terhadap kontaminan dihitung menggunakan rumus rata-rata, yaitu:

$$
\mathrm{R}=\frac{J \text { kemurnian } D N A(U 1+U 2+U \ldots)}{J \text { total jumlah } 2 a}
$$

Keterangan:

$\mathrm{R}=$ Rata-rata

$\mathrm{J}=$ Jumlah

$\mathrm{U}=$ Ulangan

Data kualitatif dalam penelitian ini menggunakan metode deskriptif dengan mengamati hasil pita DNA yang terbentuk dari proses elektroforesis gel agarose.

\section{Analisis Data dan Pengujian Hipotesis}

Data yang diperoleh diolah menggunakan komputer dengan bantuan software SPSS dan Microsoft Excell. Kemudian data dianalisa dengan ANOVA (Analysis of $V$ ariance) menggunakan uji lanjut DMRT (Duncan's Multiple Range Test) pada taraf $\alpha=5 \%$. 


\section{HASIL DAN PEMBAHASAN}

\section{Kualitas DNA Hasil Ekstraksi}

Kualitas DNA hasil ekstraksi diuji menggunakan NanoPhotometer (Implen) untuk melihat tingkat kemurnian dan konsentrasi DNA. Kontaminasi DNA terhadap RNA dan protein terlihat pada panjang gelombang ( $\lambda$ ) $260 \mathrm{~nm}$ dan $280 \mathrm{~nm}$ yang terlihat pada Tabel 2 .

Tabel 2 memperlihatkan angka diikuti huruf yang sama menunjukkan tidak berbeda nyata, hal ini menyatakan bahwa jenis cendawan tidak berpengaruh terhadap hasil kemurnian DNA, sedangkan angka diikuti huruf yang berbeda menunjukkan berbeda nyata, hal ini menyatakan bahwa penggunaan larutan bufer ekstraksi yang berbeda yaitu CTAB dan SDS berpengaruh terhadap kemurnian DNA setiap isolat cendawan. Tingkat kemurnian DNA berhubungan dengan kualitas DNA (Hendra dan Pohan, 2009). Kemurnian DNA dinilai berdasarkan hasil perbandingan $\lambda 260 / 280$ (Morin et al., 2010). DNA yang murni memiliki hasil perbandingan $\lambda 260 / 280$ berkisar pada 1.8-2.0 (Sambrook et al., 1989), sedangkan DNA yang terkontaminasi RNA memiliki nilai lebih dari 2.0 dan DNA yang terkontaminasi protein memiliki nilai kurang dari 1.8 (Neil et al., 2011).

Tabel 2. Kemurnian DNA hasil ekstraksi dengan spektofotometer.

\begin{tabular}{lc}
\hline \multicolumn{1}{c}{ Perlakuan } & $\mathbf{2 2 6 0 / 2 8 0}$ \\
\hline Jenis Cendawan & $1.92 \mathrm{a}$ \\
1. BbP & $1.88 \mathrm{a}$ \\
2. BbPs & $1.92 \mathrm{a}$ \\
3. MaP & $1.87 \mathrm{a}$ \\
4. MaJg & $2.06 \mathrm{a}$ \\
\hline Metode Ekstraksi & $1.73 \mathrm{~b}$ \\
1. CTAB & Tidak signifikan \\
2. SDS &
\end{tabular}

\section{Keterangan:}

Angka diikuti huruf yang berbeda menunjukkan berbeda nyata dan angka diikuti huruf yang sama menunjukkan tidak berbeda nyata berdasarkan uji DMRT pada taraf $\alpha=0.05(5 \%)$.

$$
\text { DNA isolat CTAB_Bb, }
$$
CTAB_BbPs, dan CTAB_MaJg dinyatakan memiliki kemurnian baik, karena masuk kedalam rentang nilai 1.82.0 (Sambrook et al., 1989). DNA isolat CTAB_MaP memiliki nilai lebih dari 2.0 yaitu 2.1, yang menunjukkan bahwa DNA terkontaminasi oleh RNA, hal ini disebabkan oleh tidak diberikan penambahan RNAse dalam proses ekstraksi DNA. RNAse merupakan enzim pendegradasi RNA yang dapat menghilangkan RNA pada larutan DNA (Sambrook et al., 1989).

DNA isolat SDS_BbP, SDS_BbPs, SDS_MaP, dan SDS_MaJg memiliki nilai kurang dari 1.8, yang menunjukkan bahwa DNA terkontaminasi protein. Hal ini disebabkan oleh tidak diberikan penambahan Proteinase- $K$ yang berfungsi untuk menghilangkan protein dalam larutan (Murtiyaningsih, 2017). Metode SDS Trizelia (2005) menggunakan amonium asetat yang memiliki fungsi yang sama (Aidar, 2007) yaitu berfungsi untuk menghilangkan protein dan kontaminan lain dengan cara dipresipitasikan (Murtiyaningsih, 2017). Namun dalam metode SDS yang digunakan, penambahan amonium asetat tidak cukup efektif menggantikan fungsi Proteinase-K karena tidak dapat mengoptimalkan proses pelisisan sel sehingga menyebabkan kontaminasi protein.

CTAB merupakan metode konvesional yang menghasilkan nilai 
kemurnian bagus dibandingkan dengan SDS, karena CTAB memiliki kekuatan melisiskan yang kuat (Sambrook et al., 1989). Penambahan larutan 2mercaptoethanol (2-me) pada bufer CTAB berfungsi sebagai pendegradasi protein (Nugroho et al., 2017), akan tetapi 2-me merupakan larutan yang bersifat korosif terhadap kulit, mudah terbakar, dan mempunyai tingkat toksiksitas tinggi bagi penggunanya (Roth, 2016). Hasil Amplifikasi Cendawan Entomopatogen Beauveria bassiana dan Metarhizium anisopliae. Pengujian DNA secara kualitatif dilakukan menggunakan elektroforesis gel agarosa dengan konsentrasi agarose sebanyaik 1\% (30 mL $=0.03$ gram). Analisis elektroforesis bertujuan untuk menentukan keberhasilan ekstraksi DNA. Primer universal yang digunakan, yaitu ITS1 dan ITS4. Primer ITS (Internal Transcribed Spacer) digunakan dalam membedakan kulturkultur cendawan asal serangga. ITS merupakan daerah yang diusulkan sebagai barcoding cendawan (Schoch et al., 2012). Gambar 1 dan Gambar 2 menunjukkan bahwa seluruh isolat menghasilkan pita DNA tunggal. Ukuran amplikon primer ITS1/ITS4 berkisar antara 500-600 bp. Primer universal ITS yang digunakan untuk mengamplifikasi DNA ribosomal dan segala jenis cendawan akan menghasilkan fragmen spesifik dengan ukuran 500-900 bp (Brasileiro et al., 2004).

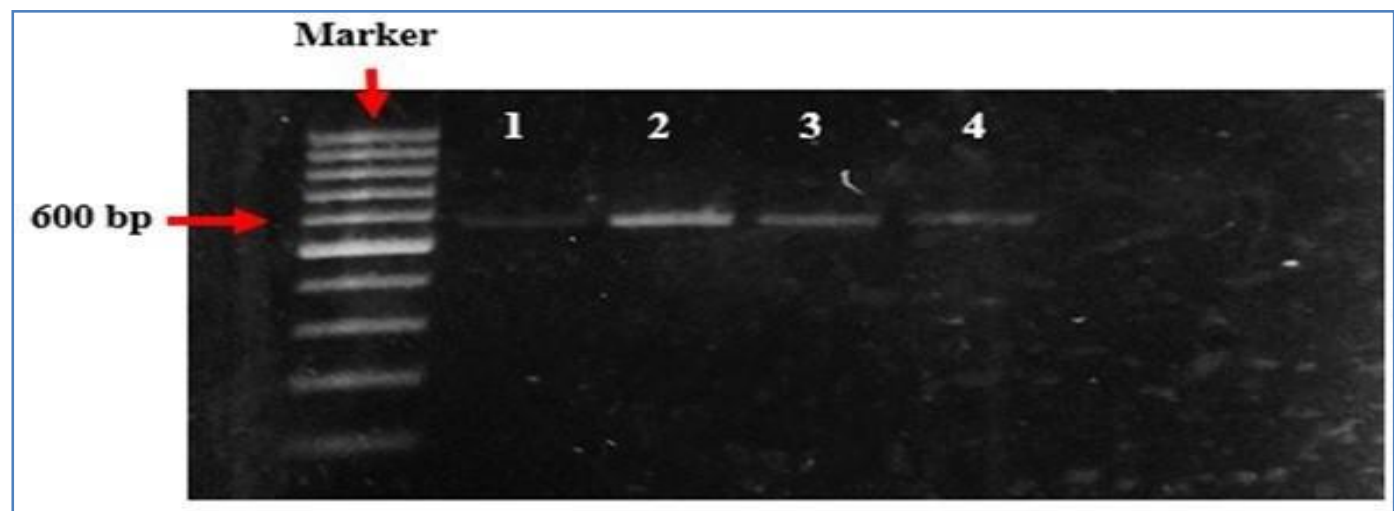

Gambar 1. Amplifikasi DNA isolat cendawan Beauveria bassiana, 1) SDS_BbP, 2) SDS_BbPs, 3) CTAB_BbP, dan 4) CTAB_BbPs.

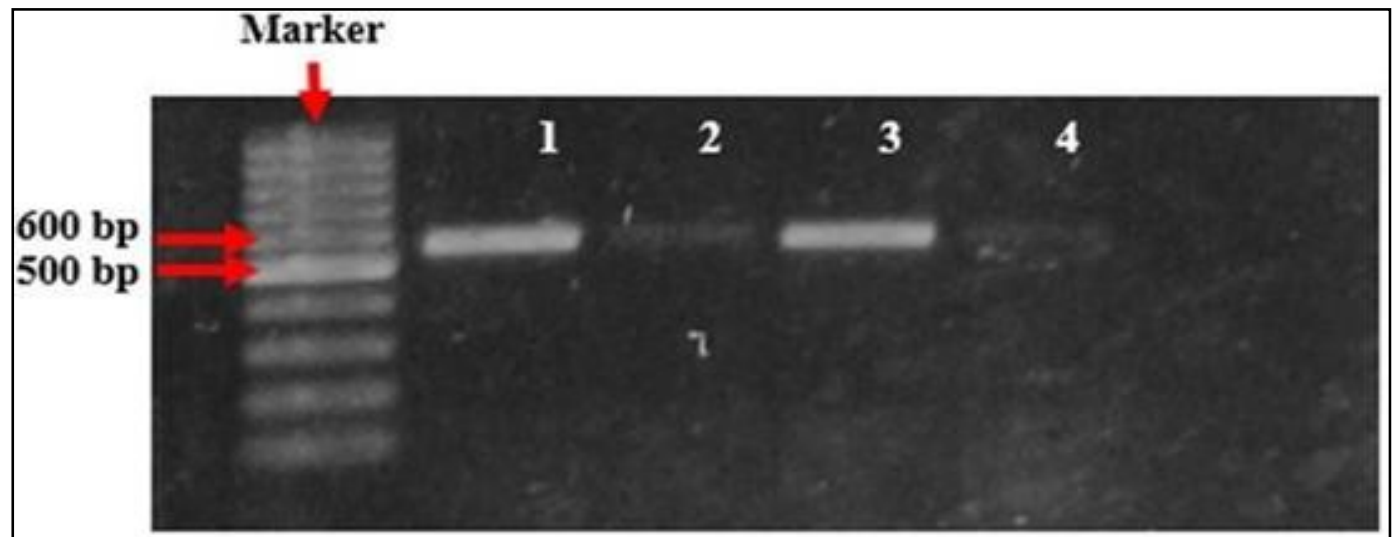

Gambar 2. Amplifikasi DNA isolat cendawan Metarhizium anisopliae, 1) SDS_MaP, 2) SDS_MaJg, 3) CTAB_MaP, dan 4) CTAB_MaJg.

Ketebalan masing-masing amplikon bervariasi, hal ini disebabkan konsentrasi DNA yang dihasilkan berbeda-beda. Ukuran amplikon pada Gambar 1 berada pada kisaran 600 bp untuk Beauveria bassiana. Penelitian Kaur 
dan Padmaja (2008) menyatakan bahwa pita DNA hasil amplifikasi pada cendawan B. bassiana diperoleh pada kisaran 320-2300 bp dan hasil penelitiannya menyatakan bahwa B. bassiana teramplidikasi pada $600 \mathrm{bp}$ asal Brazil. Ukuran amplikon Gambar 2 untuk Metarhizium anisopliae terbentuk pada kisaran 550-600 bp. Penelitian Destefano et al. (2004) menyatakan bahwa M. anisopliae teramplifikasi pada kisaran 540600 bp. M. aniosopliae var. anisopliae asal Brazil teramplifikasi pada 540 bp dan M. anisopliae var. anisopliae asal Australia pada $600 \mathrm{bp}$.

\section{KESIMPULAN}

$\begin{array}{cr}\begin{array}{c}\text { Hasil ekstraksi DNA } \\ \text { menggunakan }\end{array} & \text { buffer }\end{array}$
Cethyltrimmethylammonium Bromide (CTAB) efektif untuk isolat CTAB_BbP, CTAB_BbPs, dan CTAB_MaJg karena memiliki kemurnian pada kisaran 1.8-2.0, sedangkan isolat cendawan CTAB_MaP memiliki nilai kemurnian lebih dari 2.0, yaitu 2.1. semua isolat cendawan yang menggunakan larutan bufer Sodium Dodecyl Sulfate (SDS) memiliki nilai kemurnian kurang dari 1.8. Interaksi antara jenis cendawan entomopatogen dengan larutan bufer ekstraksi yang berbeda tidak berpengaruh terhadap kemurnian DNA karena hasil kemurnian DNA ditentukan oleh larutan bufer ekstraksi yang digunakan.

Hasil elektroforesis menggunakan primer universal ITS1/ITS4 berhasil membentuk fragmen spesifik pita tinggal DNA. Amplikon isolat cendawan B. bassiana teramplifikasi pada kisaran 600 bp, sedangkan M. anisopliae berada pada kisaran 550-600 bp.

\section{DAFTAR PUSTAKA}

Abd-Elsalam, K. A, N. A, Ibrahim, M. A, Abdel-Satar, M. S, Khalil dan J. A, Verreet. 2003. PCR Identification of Fusarium Genus based on
Nuclear Ribosomal-DNA

Sequence Data. Afr Journal Biotech. 2(4):82-85.

Aisyah, Bintang S. 2015. Keragaman Genetik Metarhizium anisopliae dan Virulensinya pada Larva Kumbang Badak (Oryctes rhinoceros). Jurnal Perlindungan Tanaman Indonesia. 19(1):12-18.

Brasileiro, B. T. R. V, Coimbra, M. R. M., de Morais, Jr. M. A. D., dan Oliveria, N. T. D. 2004. Genetic Variability within Fusarium sonali Species as Revealed by PCRFingerprinting based on PCR Markers. Braz Journal Microbiol. 35(3):205-210.

Destefano, R. H. R., Destefano, S. A., dan Messias, L. C. 2004. Detection of Metarhizium anisopliae var. anisopliae within Infected Sugarcane Borer Diatraea saccharalis (Lepidopter: Pyralidae) Using Spesific Primers. Genetics and Molecular Biology. 27(2):245-252.

Hendra, W. dan Pohan, H. G. 2009. Kajian Teknis Standar Minyak Buah Merah (Pondanus conoideus Lam.). Prosiding PPI Standardisasi. Jakarta, Indonesia.

Ikawati, B., Marbawati, D., dan Wahyudi, B. F. 2017. Efek Beauveria bassiana pada Anopheles maculatas Fase Akuatik di Laboratorium. Buletin Penelitian Kesehatan. 45(2):137-144.

Ladja, F. T. 2009. Pengaruh Cendawan Entompatogen Verticillium lecanii dan Beauveria bassiana terhadap Kemampuan Nephotettix virescens (Hemiptera: Cicadellidae) dalam Menularkan Virus Tungro. Tesis. Institut Pertanian Bogor.Bogor, Indonesia.

Morin, N., Vallaeys, T., Hendrickx, L., Natalie, L., dan Wilmotte,A. 2010. An Efficient DNA Isolation Protocol for Filamentous Cyanobacteria of the Genus 
Arthrospira. Journal Microbial Methods. 80(2):148- 154.

Murtiyaningsih, Hidayah. 2017. Isolasi DNA Genom dan Identifikasi Kekerabatan Genetika Nanas Menggunakan RAPD (Random Aplified Polimeric DNA). Agritrop. 15(1):83-93.

Neil, M. O., McPartlin, J., Arthure, K., Riedel, S., dan McMillan, N. D. 2011. Comparison of the TLDA with the Nanodrop and the Reference Qubit System. Journal Physics Conference Series. 307(1):1-6.

Nirmalasari, Cyntia. 2015. Identifikasi Beauveria sp. Asal Situ Gede dengan Analisis Sekuen Internal Transcribed Spacer dan Virulensinya terhadap Nilaparvata lugens Stal. Skripsi. Institut Pertanian Bogor. Bogor.

Nugroho, K., Terryana, R., dan Lestari, P. 2017. Metode Ekstraksi DNA Cabai (Capsicum annuum L.) Menggunakan Modifikasi Bufer CTAB (Cethyl Trimethyl Ammonium Bromide) Tanpa Nitrogen Cair. Scrita Biologica. 4(2):91-94.

Nurhasanah, Y., S. 2012. Karakterisasi Cendawan Botryodiploida thebrome dan Rhizoctonia solani dari Berbagai Tanaman Pisang Berdasarkan Morfologi dan Pola RAPD-PCR. Skripsi. Institut Pertanian Bogor. Bogor.

Porebski, S., L. G. Baily, dan B. R. Baum. 1997. Modification of CTAB

DNA Extraction Protocol for Plants Containing High Polysaccharide and Polyphenol Components. Plant Molecular Biology. 15:8-15.

Roth. 2016. Lembar Data Keselamatan. 2Mercaptoethanol. Departement of Health, Safety and Environment. Karlsruhe, Germany.

Rustama, M. M., Melanie, dan Irawan, B. 2008. Patogenisitas Jamur Entomopatogen Metarhizium anisopliae terhadap Crocidolomia pavonana fab. dalam Kegiatan Studi Pengendalian Hama Terpadu Tanaman Kubis dengan Menggunakan Agensia Hayati. Laporan Akbir Peneliti Muda UNPAD Sumber Dana DIPA UNPAD. Fakultas Matematika dan Ilmu Pengetahuan Alam. Universitas Padjajaran. Jatinangor, Indonesia.

Salim dan Hosang, M. L. A. 2013. Serangan Orycetes rhinoceros pada Kelapada Kopyor di Beberapa Sentra Produksi dan Potensi Metarhizium anisopliaesebagai Musuh Alami. Balit Palma. 14(1):47-53.

Sambrook, J., Fritsch, E. F., dan Maniatis, T. 1989. Molecular Cloning: A Laboratory Manual, 2nd Edition. Cold Spring Harbor Laboratory Press: New York.

Schoch, C. L., Seifert, K. A., dan Huhndorf, A. 2012. Nuclear Ribosomal Internal Transcribed Spacer (ITS) Region as a Universal DNA Barcode Marker for Fungi. Proceedings of the National Academy of Sciences. USA. pp 6241-6246.

Septiana, Eris. 2015. Jamur Entomopatogen: Potensi dan tantangan sebagai insektisida alami terhadap serangga perusak tanaman dan vektor penyakit manusia. BioTrends. 1(1):28-32.

Suprayogi, Marheni. 2015. Uji Efektifitas Jamur Entomopatogen Beauveria bassiana dan Metarhizium anisopliae terhadap Kepik Hijau (Nezara vidirula L.) (Hemiptera ; Pentatomidae) pada Tanaman Kedelai (Glycine max L.) di Rumah Kaca. Jurnal Online Agroteknologi. 3(1):320-327.

Trizelia, Syam, U., dan Herawaty, Y. 2010. Virulensi Isolat Metarhizium sp yang Berasal dari Beberapa Rizosfer Tanaman Terhadap 
Crocidolomia pavonana Fabricus (Lepidoptera: Pyralidae). Manggaro. 10(2):51-56.

Trizelia. 2005. Cendawan Entomopatogen Beauveria bassiana: Keragaman Genetik, Karakterisasi Fisiologi dan Virulensinya terhadap Crocidolomia pavonana.

Disertasi. Institut Pertanian Bogor. Bogor, Indonesia.

Wartono, Nirmala C., dan Suryadi, Y. 2016. Seleksi Jamur Entomopatogen Serangga Beauveria spp. Serta Uji Potegenisitasnya pada Serangga Inang Walang (Leptocorisa acuta). Berita Biologi. 15(2):175-184. 